\title{
Perancangan Video Informasi Griya Glass
}

\author{
Kevin Dimas Achda Suhudi ${ }^{1}$, Wantoro ${ }^{2}$ \\ ${ }^{I}$ Desain Komunikasi Visual, Fakultas Desain, Universitas Komputer Indonesia, Bandung \\ ${ }^{2}$ Desain Grafis, Fakultas Desain, Universitas Komputer Indonesia, Bandung \\ Email: ${ }^{1}$ kevindimas47@yahoo.co.id, ${ }^{2}$ wantoro@email.unikom.ac.id
}

\begin{abstract}
Abstrak: Kaca patri merupakan kaca berwarna, dibuat menjadi jendela dari potonganpotongan kaca yang disusun untuk membentuk gambar atau pola. Griya Glass merupakan salah satu produsen yang terletak di Bandung. Griya Glass memiliki masalah dipublikasi produk. Seperti tidak adanya konsistensi perihal dokumentasi produk kaca patri, menempelkan watermark nomor telepon dan logo pada foto menjadikan riskan penipuan yang menyebabkan tidak baiknya nama Griya Glass. Kurangnya informasi detail dari gaya desain produk. Dokumentasi kegiatan dari kualitas produk dibandingkan pada produk yang lain dan proses pengerjaan. Griya Glass sudah memiliki media sosial seperti Instagram dan Facebok, tetapi informasi tentang produk Griya Glass yang disuguhkan dicampuri dengan urusan pribadi pemilik. Tidak adanya konsistensi dalam konten dan desain media sosial membuat bingung konsumen. Maka dapat disimpulkan bahwa perlu adanya pembaruan dokumentasi dan konten melalui media sosial untuk memperbaiki sebagian besar masalah yang ada pada media sosial Griya Glass. Pembaruan konten dan hasil dokumentasi untuk media sosial Griya Glass dengan cara melakukan pendekatan melalui penyebaran video informasi sebagai bentuk penyampaian pesan pada khalayak sasaran yang dituju. Sarana informasi berbasis video merupakan sarana menyebarkan informasi tentang sesuatu hal yang penting bagi penerima yang bertujuan untuk berusaha meyakinkan khalayak agar mengetahui dengan baik tentang informasi produk maupun perusahaan yang akan disampaikan.
\end{abstract}

Kata kunci: Informasi, Konsumen, Kaca Patri, Griya Glass, Video.

\begin{abstract}
Stained glass is stained glass, made into a window of pieces on glass arranged to be images or patterns. Griya glass is one of the stained glass producers located in Bandung. Griya glass is having some troubles on production as there is no consistency in documentation of stained glass products, sticking phone number as their watermark and logo on photos puts the their reputation at risk, lack of detail on the product design style and the documentation quality of the products and the making process. Griya glass has social medias such as instagram and facebook, but the information about their products posted on same page as owner's personal life posts. Fluctuation of content consistency social media design sustain consumer's confuse. In conclusion, update and post Griya Glass content, informations and products on social medias is necessary to decrease some of their problems. An information video is a fresh approach to inform everything happen and made by Griya Glass to their consumers. A video-based platform of information is mean spreading information about something important, to the audience, that intend to try to convince people about the products and Griya Glass itself so well.
\end{abstract}

Keywords: Information, Consumer, Stained glass, Griya Glass, Video.

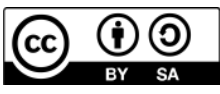




\section{PENDAHULUAN}

Kaca merupakan bagian dari setiap bangunan seperti pada bagian jendela maupun pintu. Kaca memiliki fungsi seperti penghalang panas matahari atau menciptakan transparansi visual dan fungsi estetika untuk meningkatkan seni keindahan bangunan. Seringkali ketika melihat bangunan ada banyak jenis kaca dekoratif yang membuatnya terlihat indah dan nyaman. Kaca dekoratif yang digunakan seperti kaca patri. Kaca patri berasal dari Bahasa Inggris, yaitu Stained Glass yang merupakan bahan kaca warna bertekstur yang dibuat menjadi jendela dari potongan-potongan kaca yang disusun untuk membentuk pola atau gambar, kaca dihubungkan secara manual menggunakan timah atau kuningan (Hartanti, 2014). Kaca patri dominan digunakan di gereja atau katedral, karena selain menjadi pusat keagamaan, gereja juga merupakan pusat seni desain dan pembuatan kaca patri yang ditentukan oleh ketentuan gereja berdasarkan ajaran agama (Hutama, 2005).

Berdasarkan Kementerian Pendidikan dan Kebudayaan (2015) di Indonesia, lukisan kaca pertama kali dikembangkan sebagai seni rumah tangga di jawa barat cirebon, sebagai warisan dari teknik pencontohan orang Belanda. Di Indonesia sendiri ada beberapa bangunan yang menggunakan kaca patri, terutama di kota Bandung. Berbagai gaya dan bentuk diterapkan pada kaca patri oleh pengrajin. Salah satu pengrajin kaca patri yaitu Griya Glass yang ada di kota Bandung.

Griya Glass merupakan merek bisnis yang bergerak dibidang seni kaca. Seni kaca yang dibuat oleh pengrajin Griya Glass ini diantaranya adalah kaca patri dari kuningan, kaca patri dari nikel (perak), kaca patri dari timah, kaca gravier atau etsa, kaca yang dicat atau dilukis, kaca bevel (pinggul) dan kaca inlay. Upaya yang telah dilakukan Griya Glass dalam menyebarkan informasi mengenai produknya yaitu melalui media sosial seperti Instagram dan Facebook, serta informasi secara personal dari pelanggan Griya Glass kepada calon konsumen atau secara istilah dari mulut ke mulut. Sementara Griya Glass memiliki keunggulan utama yang tidak diinformasikan tentang pemasarannya, yaitu aspek layanan optimal yang memiliki peluang untuk menciptakan kepercayaan lebih dalam benak konsumen dan pengawasan kualitas kaca patri. Konsumen dapat berkonsultasi tentang konsep, ukuran, harga, proses, dan finishing, sehingga Griya Glass dapat mengarahkan dan memberikan pilihan yang tepat dan sesuai dengan permintaan konsumen.

Griya Glass mencoba menjalin hubungan baik dengan konsumen, produsen dibidang yang sama dan produsen dibidang lain tetapi masih dilingkup yang sama, sehingga dapat bekerja sama dengan satu sama lain untuk mencapai sesuatu yang diharapkan. Dibalik usaha seni kaca, Griya Glass tidak luput dari beberapa masalah seperti pada publikasi dan informasi produk. Contohnya adalah tidak adanya konsistensi perihal dokumentasi pada media sosial, menempelkan watermark nomor telepon dan logo pada foto menjadikan riskan penipuan yang menyebabkan jeleknya nama Griya Glass. Kurangnya informasi detail dari gaya desain produk, layanan dan tidak adanya dokumentasi kegiatan dari kualitas produk dibandingkan pada produk yang lain dan proses pengerjaan. Griya Glass sudah memiliki media sosial seperti Instagram dan Facebok, tetapi informasi tentang produk Griya Glass 
yang disuguhkan dicampuri dengan urusan pribadi pemilik. Tidak adanya konsistensi dalam konten dan desain media sosial berbeda-bedajuga membuat bingung konsumen. Kurangnya informasi lengkap mengenai produk kaca patri yang diproduksi Griya Glass membuat konsumen bingung perihal pemesanan produk. Griya Glass belum memberikan arahan cara untuk memesan kaca patri kepada konsumen dan calon konsumen.

Jika masalah ini dibiarkan akan berdampak keraguan publik karena Griya Glass dianggap tidak profesional pengolahan dalam media dan secara branding tidak akan memiliki citra yang baik di mata konsumen, sehingga dapat menimbulkan stigma buruk atau ketidak percayaan pada kualitas produk Griya Glass. Pembaruan dokumentasi dan konten melalui media sosial sepertinya dapat digunakan Griya Glass untuk memperbaiki sebagian besar masalah yang ada pada media sosial Griya Glass. Maka dari itu pembaruan konten dan hasil dokumentasi yang baik dapat menjadikan media sosial Griya Glass konsisten dandapat digunakan untuk membagi informasi tentang seni kaca seperti kaca patri terhadap konsumen Griya Glass.

\section{METODE}

Dalam perancangan video informasi ini terdapat dua metode utama yang meliputi strategi kreatif dan strategi komunikasi yang dirancang sesuai dengan Griya Glass dan konsumen sebagai target audiensnya.

Pendekatan komunikasi dalam perancangan ini menggunakan pendekatan gaya hidup. Menurut Kotler dan Keller gaya hidup dapat mengekspresikan aktivitas seseorang melalui minat dari opininya terhadap sesuatu hal. Gaya hidup memperlihatkan dan menggambarkan keseluruhan orang tersebut dalam melakukan interaksi dengan lingkungan (Kotler, 2008).

Sementara alam membuat perancangan media informasi produk kaca patri dari Griya Glass, perancangan informasi perlu diterima dengan baik oleh konsumen.Perencanaan media informasi dilakukan dengan memperhatikan beberapa aspek, yaitu bentuk media informasi, konten yang akan disajikan di media informasi, serta tujuan dari desain media informasi juga dipertimbangkan.

\section{Objek Penelitian}

Objek penelitian dalam perancangan ini yaitu Griya Glass. Griya Glass merupakan pengrajin bisnis dibidang seni kaca. Griya Glass berdiri pada tahun 1994. Nama Griya Glass, diambil darikata griya yang diambil dari workshop-nyaterletak di perumahan Griya Indah Ciwastra dan glass itu sendiri adalah kaca, nama yang diberikan oleh Rudi Suherman selaku pemilik Griya Glass. Produk yang ditawarkan oleh Griya Glass ialah produk seni kaca seperti kaca patri kuningan, kaca patri nikel, kaca patri timah, gravier atau kaca etsa, kaca lukis, kaca bevel dan kaca tatahan. 


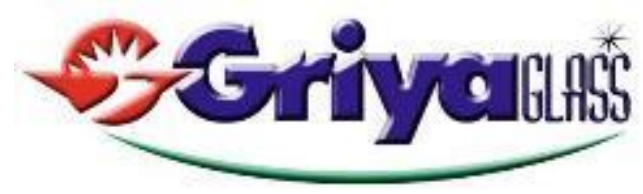

Gambar 1. Logo Griya Glass

Griya Glass menempatkan sebagai pembuat produk dari seni kaca, kebanyakan konsumen butuh produk, Griya Glass akan penuhi produk kaca seni yang diinginkan oleh konsumen, dan membuat produk sendiri. Terkecuali ada hal lain yang berhubungan dengan kaca, seperti kaca laminated, kaca tempered, atau kaca lengkung.

\section{Prosedur Pengambilan Data}

Langkah pertama yang dilakukan oleh peneliti adalah melakukan observasi. Observasi dilakukan dengan mempelajari dan melakukan pengamatan langsung terhadap perusahaan untuk mendapatkan bukti yang mendukung dan melengkapi data serta sebagian informasi mengenai teori dalam hal yang berhubungan dengan kaca patri.

Observasi dilakukan di Griya Glass, Jalan Pesona Alam II blok C9 No.1, Buah Batu, Bojongsoang, Bandung, Jawa Barat. Observasi ke workshop dirasa sangat penting untuk merasakan langsung kegiatan di lapangan dengan teknik dokumentasi agar memahami yang dilakukan Griya Glass untuk membuat kaca patri.

Kedua, dilakukan wawancara dengan Pak Rudi selaku pemilik sekaligus pengrajin sebagai informan kunci kaca patri di Griya Glass Bandung, Jalan Pesona Alam II blok C9 No.1, Buah Batu, Bojongsoang, Bandung, Jawa Barat. Wawancara dilakukan untuk menggali informasi mendalam tentang Griya Glass.

\section{Metode Analisa}

\section{1) Target Audiens}

Dalam perancngan ini ditetapkan target audiens secara spesifik dengan membagi kedalam beberapa kategori, yaitu: masyarakat Kota Bandung dalam rentang usia 35 sampai 60 tahun yang sudah memiliki rumah pribadi baik lakilaki ataupun perempuan dengan status sosial menengah keatas. Khalayak sasaran ditujukan pada orang-orang yang memiliki jiwa seni terhadap bangunan, menyukai kegiatan menggunakan fasilitas ruangan, memiliki minat dalam seni kaca yang memiliki nilai dalam hal kualitas dan asal pembuatannya, mengikuti perkembangan zaman, suka bersosialisasi dengan lingkungan sekitarnya.

\section{2) Strategi Komunikasi}

Dalam membuat perancangan media informasiproduk kaca patri dari Griya Glass,perancangan informasi perlu diterima dengan baik oleh konsumen. 
Perencanaan media informasi dilakukan dengan memperhatikan beberapa aspek, yaitu bentuk media informasi, konten yang akan disajikan di media informasi, serta tujuan dari desain media informasi juga dipertimbangkan.

Griya Glass pada saat ini belum optimal dan kurang menginformasikan potensi dan keunggulan, menjadi salah satu faktor penyebab tidak profesional dan kurang baik dimata konsumen. Maka dari itu diperlukannya sebuah media yang bersifat informatif, kreatif, dan inovatif dengan mempertimbangkan berbagai hal agar pesan dapat tersampaikan melalui multimedia dengan tepat pada khalayak sasaran yang dituju.

\section{Tujuan dan Pendekatan Komunikasi}

Tujuan komunikasi yaitu untuk menciptakan presepsi bersama atau mengubah sudut pandang, sikap, opini atau pendapat (Nugroho, 2008). Perancangan suatu media informasi dan tujuan komunikasi sangat penting agar informasi yang dibutuhkan akan tersampaikan pada khalayak sasaran baik untuk memberikan pengetahuan dan pemahaman tentang Griya Glass dengan cara merancang media informasi yang dapat tampil secara konsisten dan merepresentasikan layanan optimal yang memiliki peluang untuk menciptakan kepercayaan lebih dibenak konsumen.Konsumen dapat berkonsultasi sehingga Griya Glass dapat mengarahkan dan memberikan pilihan yang tepat dan sesuai dengan permintaan konsumen dan benar-benar mengutamakan pengawasan kualitas seni kaca dan proses pengerjaan.

Pendekatan komunikasi dalam perancangan ini menggunakan pendekatan gaya hidup. Menurut Kotler dan Keller (2008) gaya hidup dapat mengekspresikan aktivitas seseorang melalui minat dari opininya terhadap sesuatu hal. Gaya hidup memperlihatkan dan menggambarkan keseluruhan orang tersebut dalam melakukan interaksi dengan lingkungan.

Pendekatan komunikasi kemudian dibagi menjadi pendekatan verbal dan pendekatan visual. Perancangan informasi ini memakai pendekatan verbal dengan menggunakan Bahasa yang baku dan formal, karena segmentasinya usia 35-60 tahun. Usia tersebut lebih memperhatikan penyampaian bahasa dan masih memperlihatkan etika, nilai dan norma melalui bahasa yang digunakan. Pendekatan visual pada video informasi menyajikan dan menampilkan beberapa unsur elemen yang menarik dan berfungsi sesuai dengan apa yang dibutuhkan pengguna. Dengan pendekatan visual yang akan disampaikan berupa video, gambar, teks dengan visualisasi yang cinematic, karena cinematography merupakan sebuah karya visual yang berisi makna pesan dalam gambar yang diambil dan pesan tersebut akan membuat penonton bermain dengan emosi dan perasaan. 


\section{Mandatory}

Griya Glass mendukung secara penuh terhadap perancangan videoinformasi Griya Glass ini, dibutuhkan dukungan serta kerjasama dengan pihak yang terkait dalam pembuatannya. Griya Glass sendiri yang memberi dukungan penuh untuk merealisasikan video informasi tersebut diantaranya: memberikan izin penelitian, memberikan izin mengambil gambar dan dokumentasi terkait kepentingan perancangan video informasi, memberikan data berupa gambar, data, yang dibutuhkan untuk perancang, serta memberikan arahan dan pemahaman dalam pembuatan kaca patri di Griya Glass.

\section{Strategi Kreatif dan Media}

Diperlukannya sebuah media yang bersifat informatif, kreatif, dan inovatif dengan mempertimbangkan berbagai hal agar pesan dapat tersampaikan melalui multimedia dengan tepat pada khalayak sasaran yang dituju. Video informasi yang disebar secara digital melalui media sosial seperti instagram dan facebook akan lebih mudah dan cepat untuk memberikan informasi kepada khalayak sasaran yang membutuhkan seputar informasi kaca patri pada Griya Glass.

\section{Copywriting}

Pertama dirancang key word yang kemudian menjadi sebuah kesimpulan "Cerita Kita Menciptakan Maha Karya" merupakan ide konten yang berada dalam video informasi yang mengarahkan pada key visual menentukan hasil dari video informasi yang akan dibuat nantinya. Kedua, video informasi diberi judul Griya Glass agar audiens mudah mencarinya. Kemudian dirancang key visual yang akan menentukan scene, storyline dan storyboard video informasi yang akan dibuat.

\section{Rancangan Visual}

Pendekatan visual yang akan disampaikan berupa video, gambar, teks dengan visualisasi yang cinematic, karena cinematography merupakan sebuah karya visual yang berisi makna pesan dalam gambar yang diambil dan pesan tersebut akan membuat penonton bermain dengan emosi dan perasaan.

Visual tersebut bertujuan untuk menggiring khalayak sasaran untuk masuk ke pencapaian yang ingin diraih untuk konsumen dan calon konsumen, seperti konsultasi konsumen pada pengrajin, proses pengerjaan secara detail, pengawasan kualitas, dan produk kaca patri hingga selesai.

\section{HASIL DAN PEMBAHASAN}

Dalam perancangan video informasi ini, langkah utama yang dilakukan adalah mencari dan menggali informasi mengenai Griya Glass itu sendiri untuk disuguhkan ke dalam video. Setelah informasi yang dibutuhkan terkumpul, kemudian dibuat ide cerita, alur storyline dan storyboard yang memuat informasi yang akan 
disampaikan. Saat konsep telah matang dibuat kemudian dilanjutkan pada proses pencarian talent dan lokasi yang cocok dengan konsep video. Selain itu, peralatan dan properti yang dibutuhkan untuk proses produksi video mulai disiapkan dan dilanjutkan pada proses pembuatan video saat semua persiapannya telah selesai. Setelah itu, hasil pengambilan gambar kemudian diedit menggunakan aplikasi yang efektif dan efisien agar menjadi sebuah video informasi yang utuh.

\section{Format Desain}

Format video pada perancangan video informasi Griya Glass ini dengan menggunakan kualitas video High Resolution 1.080 px x 720 px dengan perbandingan aspek ratio 16:9. Dengan rincian format sebagai berikut:

- Frame size: 1.080 px x 720 px

- Frame rate: $60 \mathrm{fps}$

- Aspec ratio: 16:9

- Channel: RGB

- Format video: (.mp4)

- Video code: Audio Visual

- Duration: 00:02:15

- Audio sample rate: $48 \mathrm{kHz}$

- Audio channels: Stereo

- Format Audio: mp3

\section{Tata Letak}

Layout atau tata letak adalah kompilasi dari elemen elemen desain grafis seperti pengaturan ilustrasi, teks, tabel dan lainnya, yang digabungkan menjadi satu unit untuk menjadi desain komunikasi visual yang komunikatif secara estetika (rustan, 2017).

Tata letak dalam perancangan video informasi pada Griya Glass memakai beberapa Teknik pengambilan gambar yang berbeda-beda untuk memunculkan kesan. Dalam prosesnya, pengambilan gambar meggunakan tiga teknik yang berbeda, yaitu teknik wide shoot dan extreme wideshoot. Teknik wide shot dan Extream Wide shot pengambilan gambar yang menampilkan gambar secara keseluran dengan latar belakang yang luas.

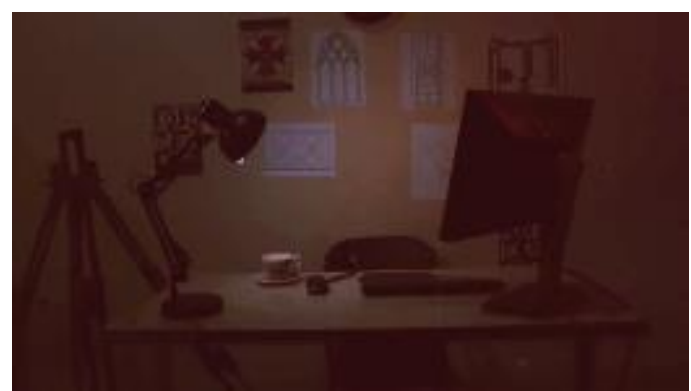

Gambar 2. Wide Shoot dan Extreme Wideshoot 
Teknik kedua yaitu teknik medium shot. Pengambilan Teknik gambar Medium Shot menampilkan bagian-bagian subjek secara sedikit lebih dekat dari wide shot. Biasanya menampilkan bagian kepala hingga pinggang jika pengambilan gambar pada objek manusia, untuk memunculkan kesan menyatu antara objek dan latar belakang.

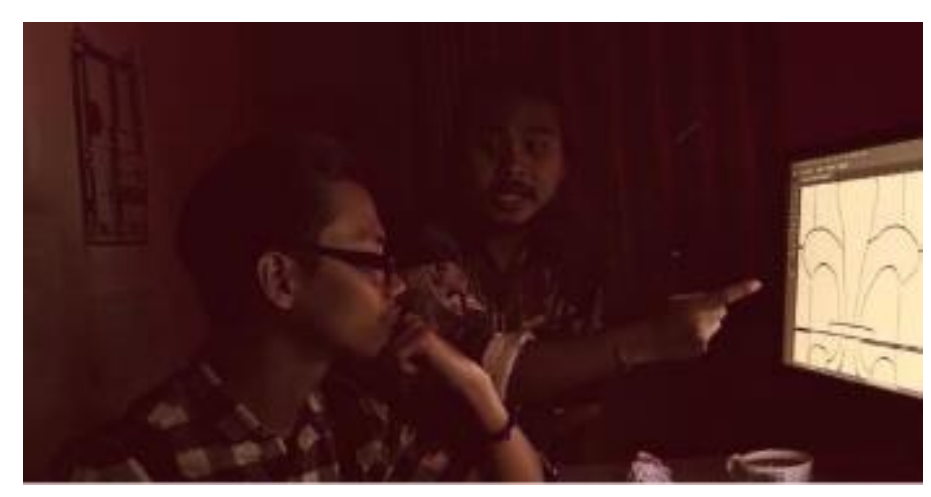

Gambar 3. Medium shot

Teknik terakhir yaitu teknik extreme close up shot. Pengambilan gambar Extream closeup shot dan Closeup shot memunculkan kesan sangat mendetail dengan objek yang menjadi fokus utamanya dalam frame layar secara keseluruhan. Biasanya menampilkan bagian-bangain tubuh tertentu manusia, untuk memunculkan kesan dramatis.

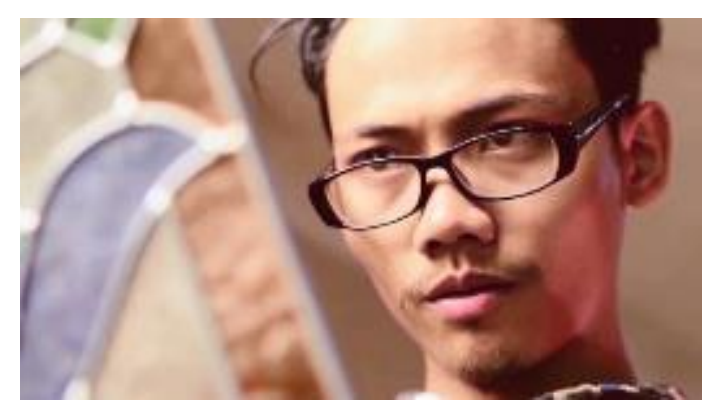

Gambar 4. Extreme Close up shot

\section{Media Pendukung}

Tata letak dalam pembuatan media pendukung menggunakan gaya Mondrian style pelukis asal Belanda yaitu Piet Mondriaan. Piet Mondrian menamakan lukisan gaya garis dengan nama neoplasticism, tetapi banyak juga yang menamainya De Stijl, merujuk pada gerakan seni. Piet Mondrian meyakini, kombinasi garis vertikal dan horizontal dengan warna-warna dasar bisa menjadi karya seni (Antyo, 2013). Pembuatan layout memakai gaya mondrian dipilih karena merujuk pada seni kaca patri yang memiliki garis vertikal, horizontal dengan menggunakan warna-warna dasar seperti merah dan biru. 


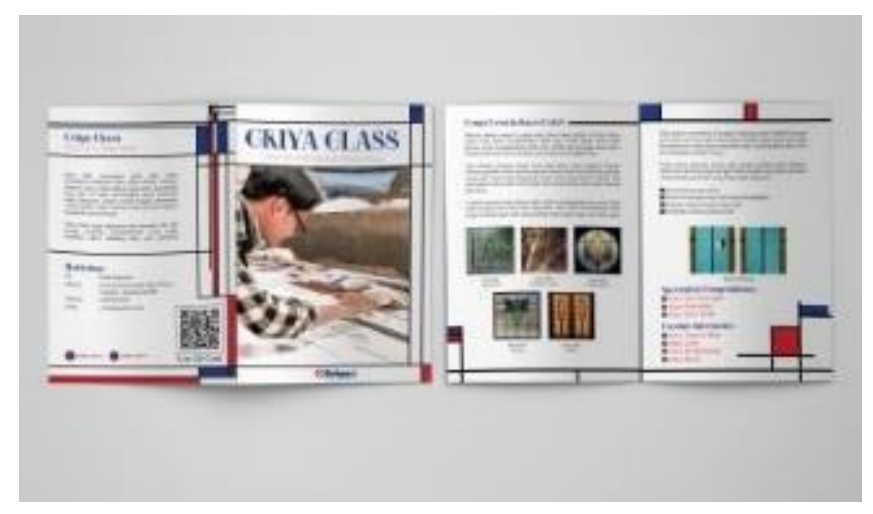

Gambar 5. Brosur

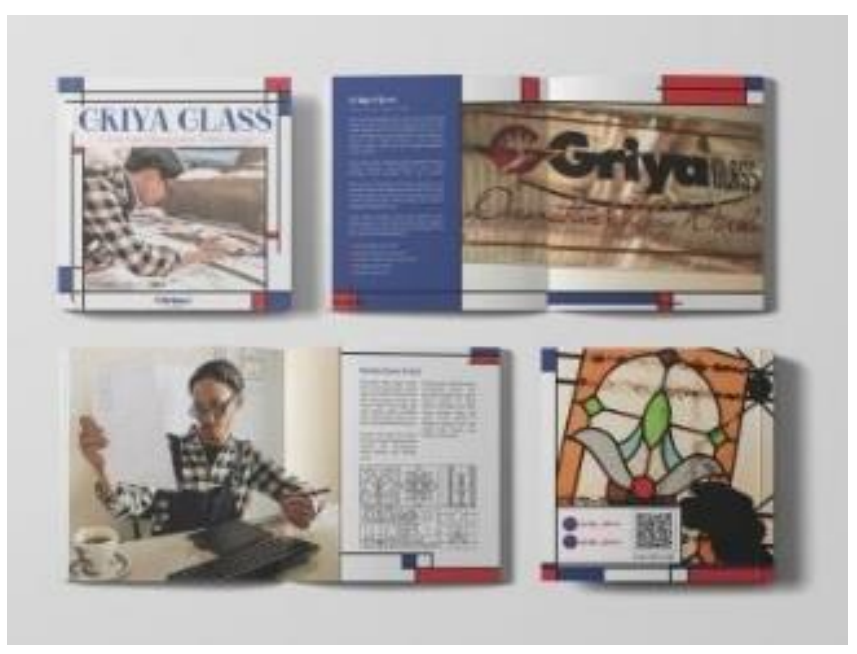

Gambar 6. Buku Profil Perusahaan

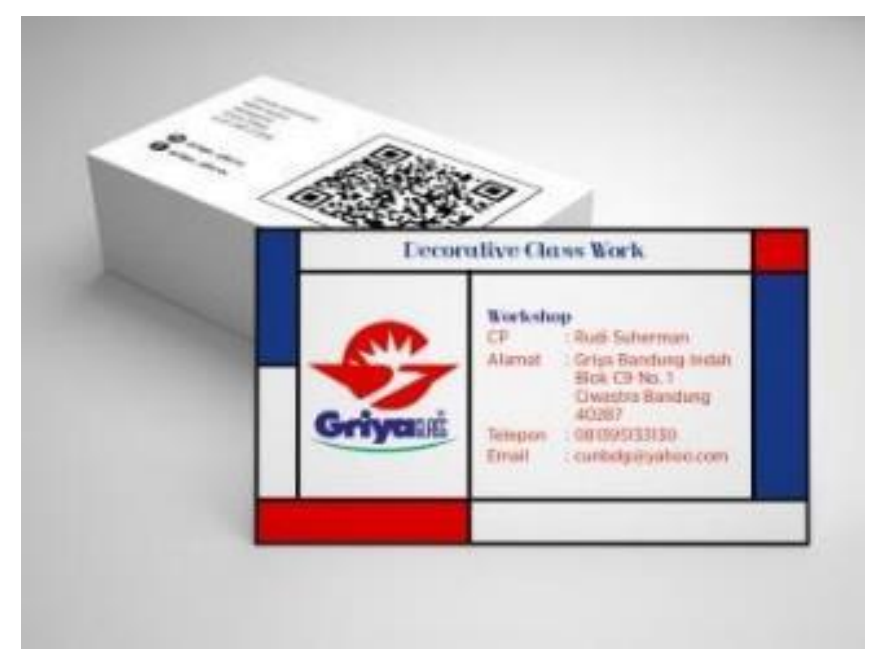

Gambar 7. Kartu Nama 
Tipografi merupakan objek visual dari bentuk penyampaian komunikasi verbal pada media utama dan pendukung dengan suasana huruf yang tertata. Huruf adalah salah satu elemen grafis yang penting untuk melengkapi suatu rancangan desain yang dipresentasikan kepada khalayak luas (Wantoro, 2017). Huruf yang digunakan pada perancanangan ini menggunakan huruf Riot Squad NF dan Poiret One.

\section{KiolSquadII}

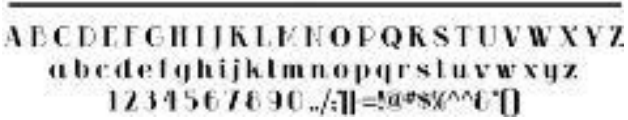

Gambar 8. Font Riot Suad NF

Dipilih karena bentuk huruf yang terkesan klasik dan cocok dengan menyerupai unsur-unsur pola kaca patri yang lurus dan melengkung dibuat dengan keterampilan tangan hingga menghasilkan suatu bentuk yang elegan huruf tersebut dapat digunakan untuk tanda- tanda besar, label, judul dan kata utama.

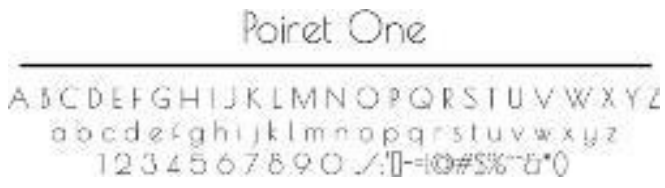

Gambar 9. Font Poiret One

Dipilih karena tipe unik dengan bentuk yang halus dan sederhana. Berdasarkan bentuk geometris, ini memiliki garis yang bergaya dan lengkungannya anggun. font tersebut dapat digunakan untuk subjudul, berita dan semua jenis informasi atau dalam bentuk cetakan dari banner hingga brosur.

\section{Ilustrasi}

Illustrasi pada perancangan video informasi Griya Glass melalui pendekatan gaya hidup dengan mengillustrasikan di ruangan terlihat suasana yang menampilkan meja kerja, layar LCD. Lampu meja, kursi, cangkir dan standlukis dengan tembok dihiasi pajangan dan gambaran atau sketsa.

Pendekatan visual yang akan disampaikan berupa video, gambar, teks dengan visualisasi yang cinematic, karena cinematography merupakan sebuah karya visual yang berisi makna pesan dalam gambar yang diambil dan pesan tersebut akan membuat penonton bermain dengan emosi dan perasaan. 


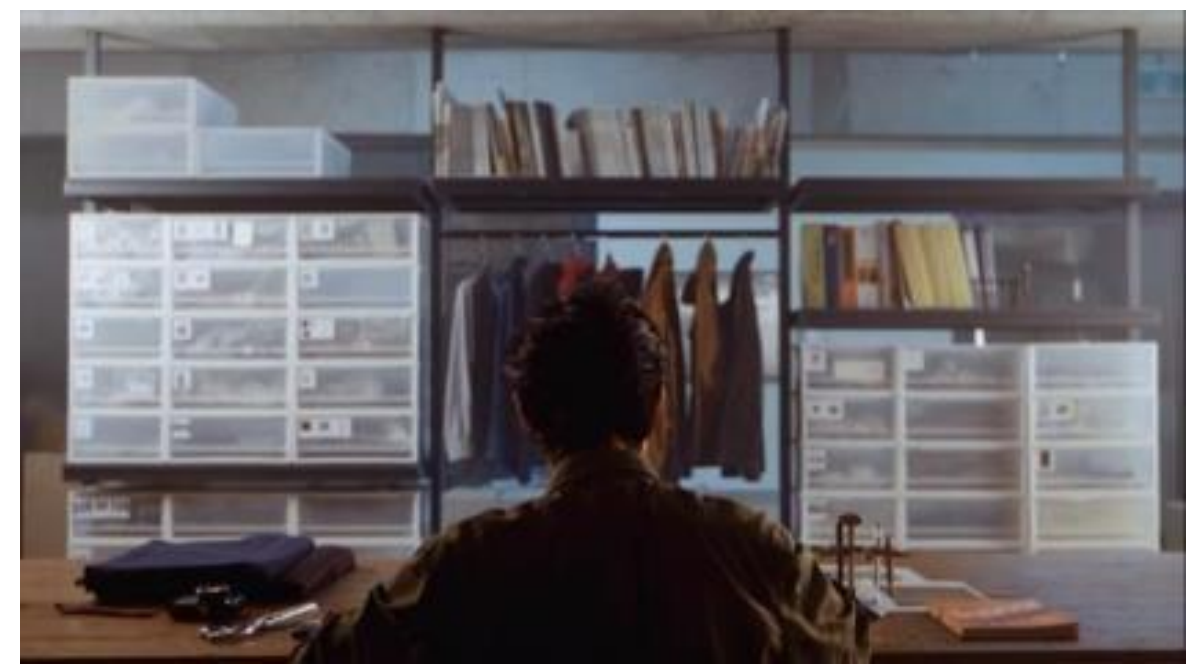

Gambar 10. Referensi plot video Bastong Clothing

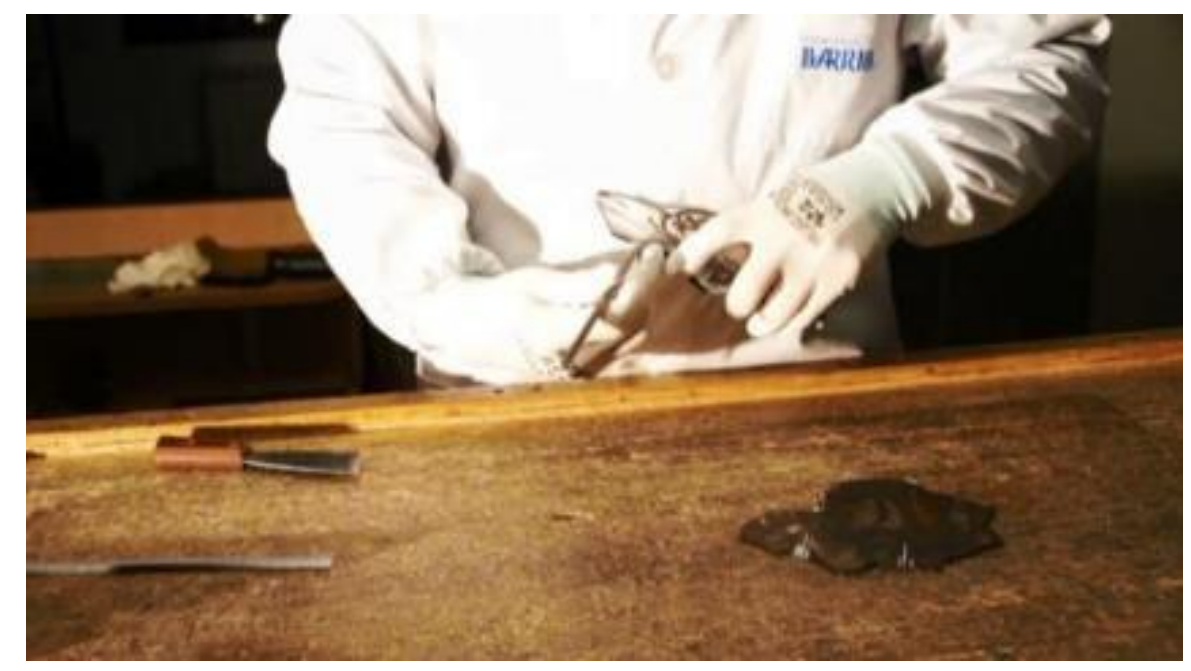

Gambar 11. Referensi video pembuatan kaca patri

\section{KESIMPULAN}

Maka dapat disimpulkan video informasi dirasa cocok untuk pembaruan dokumentasi dan konten melalui media sosial dapat digunakan Griya Glass untuk memperbaiki sebagian besar masalah yang ada dimedia sosial Griya Glass, maka dari itu pembaruan konten dan hasil dokumentasi yang baik untuk menjadikan media sosial Griya Glass konsisten dan membagi informasi tentang seni kaca seperti kaca patri terhadap konsumen Griya Glass pada khalayak sasaran yang dituju dari informasi pesan yang memiliki alur cerita pada video informasi tersebut. 


\section{DAFTAR PUSTAKA}

Antyo (2013, Maret 07). Gaya Kotak-Kotak Mondriaan dan Mondrian. Beritagar.id. Dikutip dari https://beritagar.id/artikel/gaya-hidup/7-maret-gaya-kotak-kotakmondriaan- dan-mondrian (diakses: 29 Januari 2020)

Hartanti, G. (2014). Aplikasi Kaca Pada Perancangan Desain Interior dan Arsitektur. Humaniora, vol. 5(2), 764.

Hutama, K. (2005). Seni Ragam Hias Stained Glass pada Bangunan-Bangunan di Jakarta. Dimensi, vol. 2(2), 101-106.

Kementerian Pendidikan dan Kebudayaan. (2015). Seni Budaya. Jakarta: Kementerian Pendidikan dan Kebudayaan.

Kotler, P. (2008). Manajemen Pemasaran Edisi 12 Jilid 2. Jakarta: Indeks

Nugroho, E. (2008). Pengenalan Teori Warna. Yogyakarta: CV Andi Offset (Penerbit Andi).

Rustan, S. (2017) Layout, Dasar \& Penerapannya. Jakarta: Gramedia Pustaka Utama.

Wantoro, W., \& Kasmana, K. (2017). Perancangan Font Tapych Berbasis Karakter Visual Motif Tapis Lampung. ANDHARUPA: Jurnal Desain Komunikasi Visual \& Multimedia, 3(01), 81-91. 